\title{
An AC-AC high frequency pulse density modulated full bridge series resonant converter for induction heating application
}

\author{
V.Geetha, V. Sivachidambaranathan \\ Department of Electrical and Electronics Engineering, Sathyabama Institute of Science and Technology, India
}

\begin{tabular}{l} 
Article Info \\
\hline Article history: \\
Received Sep 7, 2018 \\
Revised Nov 26, 2018 \\
Accepted Dec 15, 2018 \\
\hline
\end{tabular}

\section{Keywords:}

Power

Pulse density modulation

Total harmonic distortion

\begin{abstract}
This paper deals with a new AC-AC single stage full bridge series resonant converter for induction heating application. The proposed system is simulated with high power density modulation technique to produce an output power of $1.8 \mathrm{Kw}$. The main feature of the proposed converter is to reduce the total harmonic distortion produced in the output current for the switching frequency of $29 \mathrm{Khz}$.Asymmetrical pulse density modulation technique is proposed to achieve maximum output power with less harmonic content. It is found that the THD of the proposed high-power density modulated converter is $13.43 \%$. Here, the validity of the proposed converter for domestic induction heating application is compared and summarized.
\end{abstract}

Copyright () 2019 Institute of Advanced Engineering and Science. All rights reserved.

\section{Corresponding Author:}

V. Geetha,

Research Scholar, Department of Electrical and Electronics Engineering,

Sathyabama Institute of Science and Technology,

Jeppiaar Nagar, Chennai, Tamil Nadu 600119, India.

Email: geethasendray28@gmail.com

\section{INTRODUCTION}

Induction heating system is the quite advanced heating system in the current scenario. This system is a contactless heating, fastness in heating, cleanliness and safety is the essential factors to be considered during heating process [1]. The principle behind the induction heating process is faradays law of electromagnetic principle. Here the material to be heated and the heating element do not come in contact. The material to be heated behaves coil 1 and heating element as coil 2 . Principle of mutual inductance is applied [2]. The heating process is done in two ways one is eddy current and the other is hysteresis effect. The effect of transferring the heat energy to the working material from the heating element is called joule effect. There are other heating technologies like flame heating, resistance heating, traditional oven heating [3]. In medicinal application like heating of the biological tissues during the treatment of the cancer patients during radiotherapy converting the high frequency to the ultra high frequency for uniform spreading of the heat energy with a temperature of $25^{\circ} \mathrm{C}$ and a power of 40 watts [4]. The methodology of the system is single stage (AC-AC) and multi stage operation (AC-DC-AC) this stages in operation is only to convert utility frequency input to the high frequency input which is the major requirement for the operation [5]. The recent issues of IH system deals with half and full bridge converter both in the field of industrial and domestic purpose. In industrial application like melting of alloys, forging, hardening etc. The most efficient method employed is IH system. [6-11]. Depending on the load there are other classifications like series connected load, parallel connected load, series parallel connected load [12].

This paper discusses about the single stage full bridge AC-AC converter for induction heating application in the following section II discussion is about description of the proposed converter,section III the modes of operation is elaborated and in section IV the essential results of the proposed converter is discussed. The comparison of the converter is made in section $\mathrm{V}$. 


\section{DESCRIPTION OF THE PROPOSED FULL BRIDGE SERIES RESONANT CONVERTER}

The single stage AC-AC series resonant full bridge converter is proposed for the induction heating application in the field of domestic. The Figure1depict the proposed full bridge series resonant AC-AC converter. There are various configuration and topologies for the design of the power circuit for the induction heating application familiar and the easily accesible one is the full bridge converter. Here we have single stage aperation which will have a harmoniclesssystem. The output power required for the domestic application is found to be <2kilowatts that can be easily produced by the full bridge converter. The coil configuration can be series, series parallel or parallel to have efficient performance of the system series connection of the elements is preffered. Checking on the resonance condition of the coil the switching frequency is selected satisfying the condition $\mathrm{F}=1 / 2 \pi \mathrm{RC}$.

For the choosen switching frequency the type modulation used should be high power density modulation for converting the utility frequency to the high frequency output. There are different types in the power density modulation one is assymmetrical and symmetrical pulse density modulation. The comparison of the results is between the two techniques and modes of operation are framed according to the pulse width.

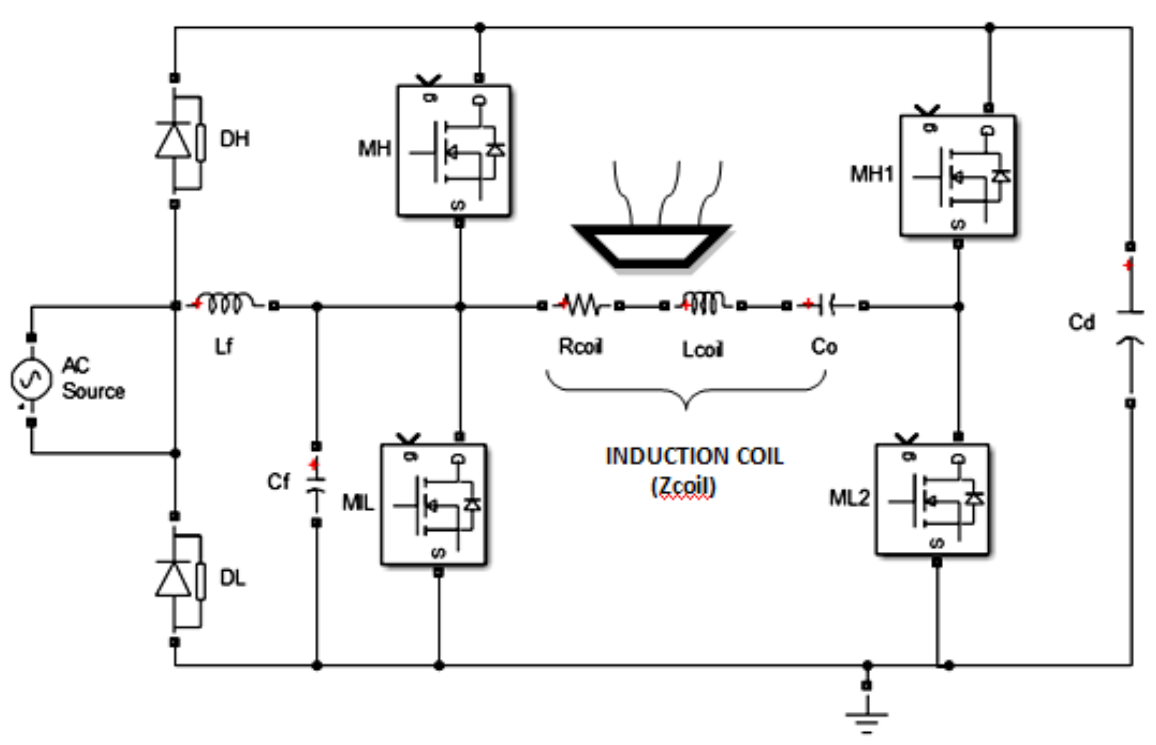

Figure 1. Full bridge series resonant converter for IH applications

\section{MODES OF OPERATION}

The operation of the circuit comprises of four modes from origin of the pulse generation and end of the single pulse this repeated $n$ number of times in the one half a cycle. The operation depends on the charging and discharging the capacitor in the circuit prescribed in Figure 1. The on and off condition of the switches present in the circuit is summarised at the end of the section which clearly depicts the flow of operation and in each mode the equivalent circuit path is shown for the reference to make the analysis of each mode in Table 1. The modes of the proposed system is elaborated in the section.

Table 1. Summarization of modes of operation

\begin{tabular}{clll}
\hline Modes & Condition of the switch & Inference & Time period \\
\hline Mode 1 & $\mathrm{M}_{\mathrm{H}, \mathrm{M}_{\mathrm{L1}} \text { (on state) }}$ & $\mathrm{V}_{\text {out }}=0$ & $\mathrm{~T}=0$ \\
& & $\mathrm{~V}_{\text {out }}=\mathrm{V}_{\mathrm{S}}$ & $0<\mathrm{T}<\mathrm{t}_{1}$ \\
Mode 2 & $\mathrm{M}_{\mathrm{L}}, \mathrm{M}_{\mathrm{L1}}$ (on state) & $\mathrm{V}_{\text {out }}=0$ & $\mathrm{~T}=\mathrm{t}_{1}$ \\
& $\mathrm{D}_{\mathrm{L}}=\mathrm{RB}$ & $\mathrm{V}_{\text {out }}=\mathrm{V}_{\text {co } \uparrow}$ & $\mathrm{t}_{1}<\mathrm{T}<\mathrm{t}_{2}$ \\
Mode 3 & $\mathrm{M}_{\mathrm{L}}, \mathrm{M}_{\mathrm{H} 1}$ (on state) & $\mathrm{V}_{\text {out }}=0$ & $\mathrm{~T}=\mathrm{t}_{2}$ \\
& $\mathrm{D}_{\mathrm{L}}=\mathrm{FB}$ & $\mathrm{V}_{\text {out }}=\mathrm{V}_{\text {co } \downarrow}$ & $\mathrm{t}_{2}<\mathrm{T}<\mathrm{t}_{3}$ \\
\multirow{2}{*}{ Mode 4 4} & $\mathrm{M}_{\mathrm{L}}, \mathrm{M}_{\mathrm{H} 1}$ (on state) & $\mathrm{V}_{\text {out }}=0$ & $\mathrm{~T}=\mathrm{t}_{3}$ \\
& $\mathrm{D}_{\mathrm{L}}=\mathrm{FB}$ & $\mathrm{V}_{\text {out }}=\mathrm{V}_{\mathrm{CD}}=\mathrm{V}_{\mathrm{S}}$ & $\mathrm{t}_{3}<\mathrm{T}<\mathrm{t}_{4}$ \\
\hline
\end{tabular}




\subsection{Mode $1\left(0<\mathrm{T}<\mathrm{t}_{1}\right)$}

Here the power switch $\mathrm{M}_{\mathrm{H}}$ and $\mathrm{M}_{\mathrm{L} 1}$ is under on state and the flow of current in the circuit from the supply is divided in to two paths and named as $\mathrm{I}_{1}$ and $\mathrm{I}_{2}$ and the total current of $\mathrm{I}$. The period of on condition of the power switches is from 0 to $t_{1}$ for the positive half cycle of the operation with assymmetrical pulse density modulation. The equivalent circuit is depicted in the Figure 2 showing forward mode of operation the output voltage and the current follows the applied input voltage till the power switch is in the on state.

$$
\begin{aligned}
& \mathrm{I}=\mathrm{I}_{1}+\mathrm{I}_{2} \\
& \mathrm{~V}_{\mathrm{S}}=\mathrm{V}_{\mathrm{m}} \operatorname{Sinwt} \\
& \mathrm{V}_{\text {cd }}=\mathrm{V}_{\text {coil }}=\mathrm{V}_{\mathrm{s}} \\
& \text { So, } \\
& \mathrm{V}_{\text {cd }}=1 / \mathrm{C}_{\mathrm{d}} \int \mathrm{I}_{2} \mathrm{dt} \\
& \mathrm{V}_{\text {coil }}=\mathrm{I}_{1} \mathrm{R}_{\text {coil }}+{ }_{\text {Lcoil }} \mathrm{dI} / \mathrm{dt}+1 / \mathrm{C}_{\mathrm{o}} \int \mathrm{I}_{1} \mathrm{dt} \\
& 1 / \mathrm{C}_{\mathrm{d}} \int \mathrm{I}_{2} \mathrm{dt}=\mathrm{I}_{1} \mathrm{R}_{\text {coil }}+{ }_{\text {Lcoil }} \mathrm{dI}_{1} / \mathrm{dt}+1 / \mathrm{C}_{\mathrm{o}} \int \mathrm{I}_{1} \mathrm{dt}
\end{aligned}
$$

Cycle continues for the period of 0 to $t_{1}$

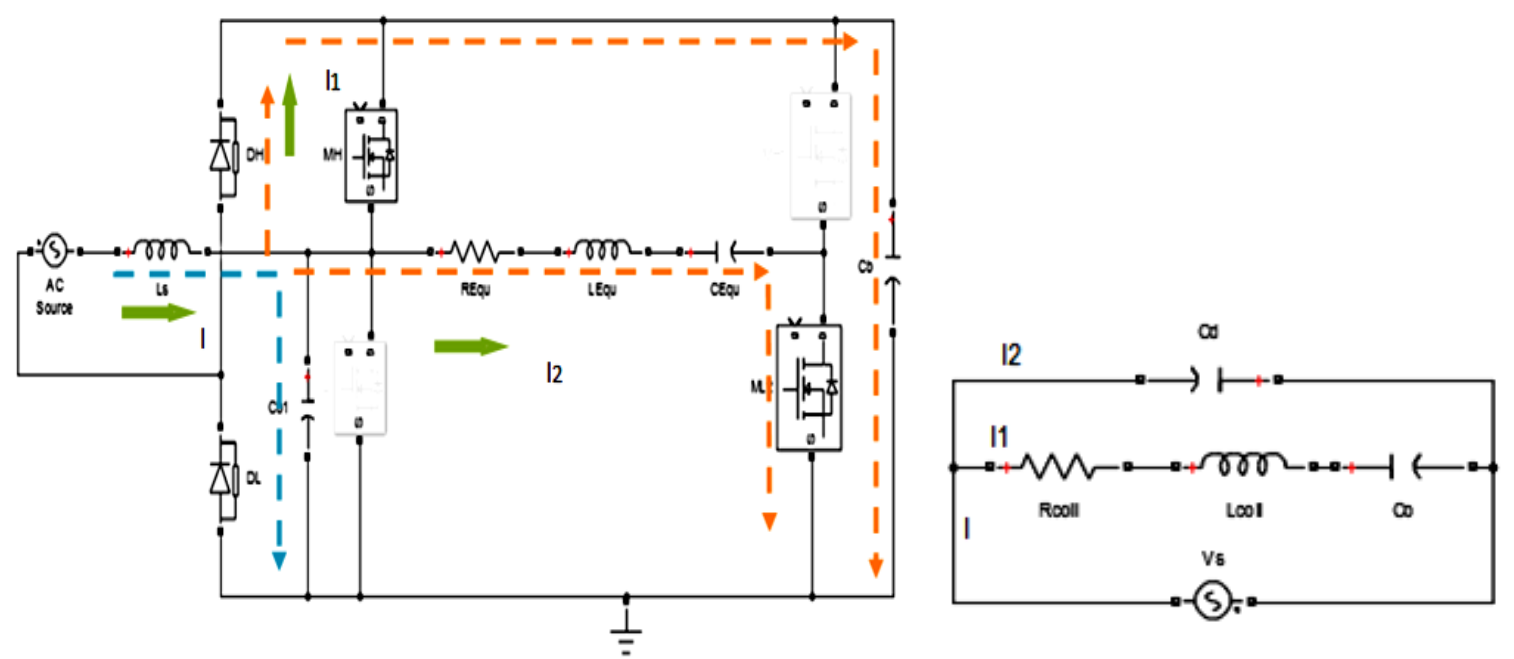

Figure 2. Mode $1\left(0<\mathrm{T}<\mathrm{t}_{1}\right)$, equivalentcircuit

$$
1 / \mathrm{C}_{\mathrm{d} 0} \int^{\mathrm{tl}} \mathrm{I}_{2} \mathrm{dt}=\mathrm{I}_{1} \mathrm{R}_{\text {coil }}+{ }_{\text {Lcoil }} \mathrm{dI} / \mathrm{dt}+1 / \mathrm{C}_{\mathrm{o} 0} \int^{\mathrm{tl}} \mathrm{I}_{2} \mathrm{dt}
$$

On solving the ratio between the currents is found to be

$$
\begin{gathered}
\mathrm{I}_{1}(\mathrm{~S}) / \mathrm{I}_{2}(\mathrm{~S})=1 /\left(1+\mathrm{RCS}+\mathrm{LCS}^{2}\right) \\
(\mathrm{OR}) \\
\mathrm{I}_{2}(\mathrm{~S}) / \mathrm{I}_{1}(\mathrm{~S})=1+\mathrm{RCS}+\mathrm{LCS}^{2}
\end{gathered}
$$

The DClink capacitor is charged to a voltage equivalent to the source voltage $\mathrm{V}_{\mathrm{s}}$. Now,

$$
\begin{aligned}
& \mathrm{V}_{\mathrm{cd}}=\mathrm{V}_{\mathrm{S}} \\
& \mathrm{V}_{\mathrm{m}} \operatorname{Sinwt}=1 / \mathrm{C}_{\mathrm{d} 0} \int^{\mathrm{t} 1} \mathrm{I}_{2} \mathrm{dt} \\
& \text { On solving we get } \\
& \mathrm{I}_{2}=\mathrm{V}_{\mathrm{m}} \mathrm{C} / \mathrm{wt}\left(\cos w \mathrm{t}_{1}-1\right)
\end{aligned}
$$

\subsection{Mode 2: $\left(\mathrm{t}_{1}<\mathrm{T}<\mathrm{t}_{2}\right)$}

By using the commutation technique the power switches $\mathrm{M}_{\mathrm{H}}$ and $\mathrm{M}_{\mathrm{L} 1}$ is put to off state and the coil carries a voltage of zero at time $\mathrm{T}=\mathrm{t}_{1}$, the $\mathrm{DC}$ link capacitorcharges to a maximum of the input voltage in Figure 3. Now the power switch $\mathrm{M}_{\mathrm{L}}$ and $\mathrm{M}_{\mathrm{L} 1}$ is put to on state,the instant the switches or put to on state. 
The diode $D_{L}$ moves to reverse bias condition and now the second path of the current flow is the discharging of the resonating capacitance has stored charge in the mode 1 now discharges and circulates the current to flow in the coil through out making the continuous flow of current through the coil now in this particular mode we have output voltage across the coil as the voltage in the storage element.

$$
\begin{aligned}
& \mathrm{V}_{\text {coil }}=\mathrm{V}_{\text {co, }} \\
& \mathrm{V}_{\text {coil }}=1 / \mathrm{C}_{0} \int \mathrm{I}_{1} \mathrm{dt}
\end{aligned}
$$

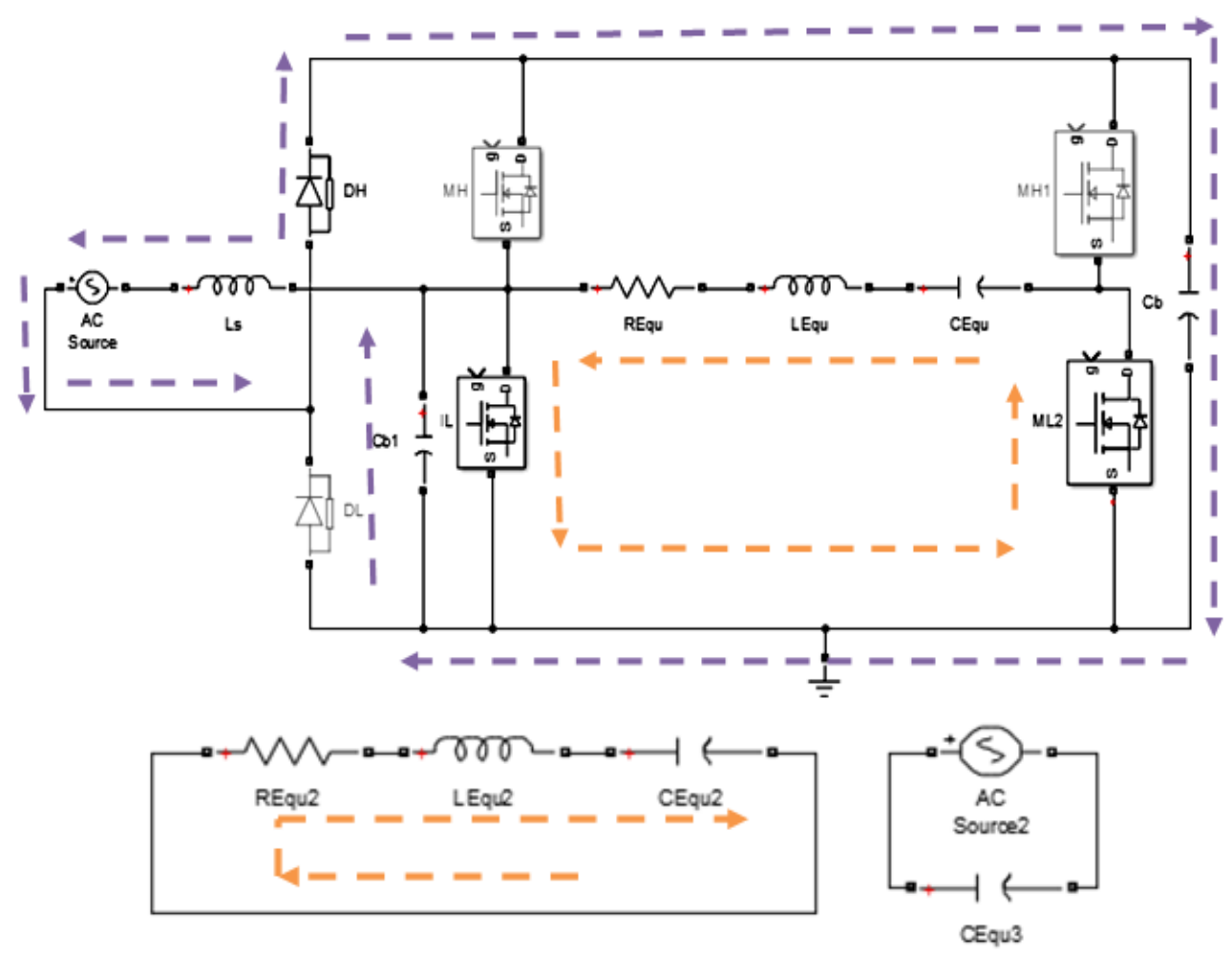

Figure 3. Mode 2: $\left(\mathrm{t}_{1}<\mathrm{T}<\mathrm{t}_{2}\right)$

\subsection{Mode 3: $\left(\mathbf{t}_{2}<\mathbf{T}<\mathbf{t}_{3}\right)$}

When the DC link capacitor is fully charged during the mode 2 operation, the excess charge from the DC link capacitor starts discharging now this discharing of the capacitor makes the current to flow in a reverse diresction so now the diode $D_{L} I S$ moved to the forward bias condition Making the power switch $M_{L 1}$ to move to off state and allowing the switch $\mathrm{M}_{\mathrm{H} 1}$ to go to on state in Figure 4. The discharging current finds the path through the coil and now we have the current from the source also flowing via coil so the additive current flows through the coil. This mode of operation allows the maximum current to flow through the coil.

$$
\mathrm{I}_{\mathrm{Coil}}=\mathrm{I}_{\text {supply }}+\mathrm{I}_{\mathrm{CD}}
$$

The voltage across the coil is found to be either $\mathrm{V}_{\mathrm{S}}$ or $\mathrm{V}_{\mathrm{CD}}$

$$
\begin{aligned}
& \mathrm{V}_{\text {Coil }}=\mathrm{I}_{\text {Coil }} * \mathrm{Z}_{\text {coil }} \\
& \mathrm{V}_{\text {Coil }}=\mathrm{V}_{\mathrm{S}}=\mathrm{V}_{\mathrm{CD}}
\end{aligned}
$$

\subsection{Mode 4: $\left(\mathbf{t}_{3}<\mathrm{T}<\mathrm{t}_{4}\right)$}

The DC link capacitor has discharged to a minimum value in the previous mode of operation in Figure 5, now the diode $\mathrm{D}_{\mathrm{L}}$ moved to the reverse bias condition following two path. The capacitor now finds the path to charge itself to the source voltage and the other path the resonating capacitor in the coil starts charging and the coil carrying the voltage in the previous mode 2 . So the cycle repeats for the times the pulse generated for the half a cycle. 

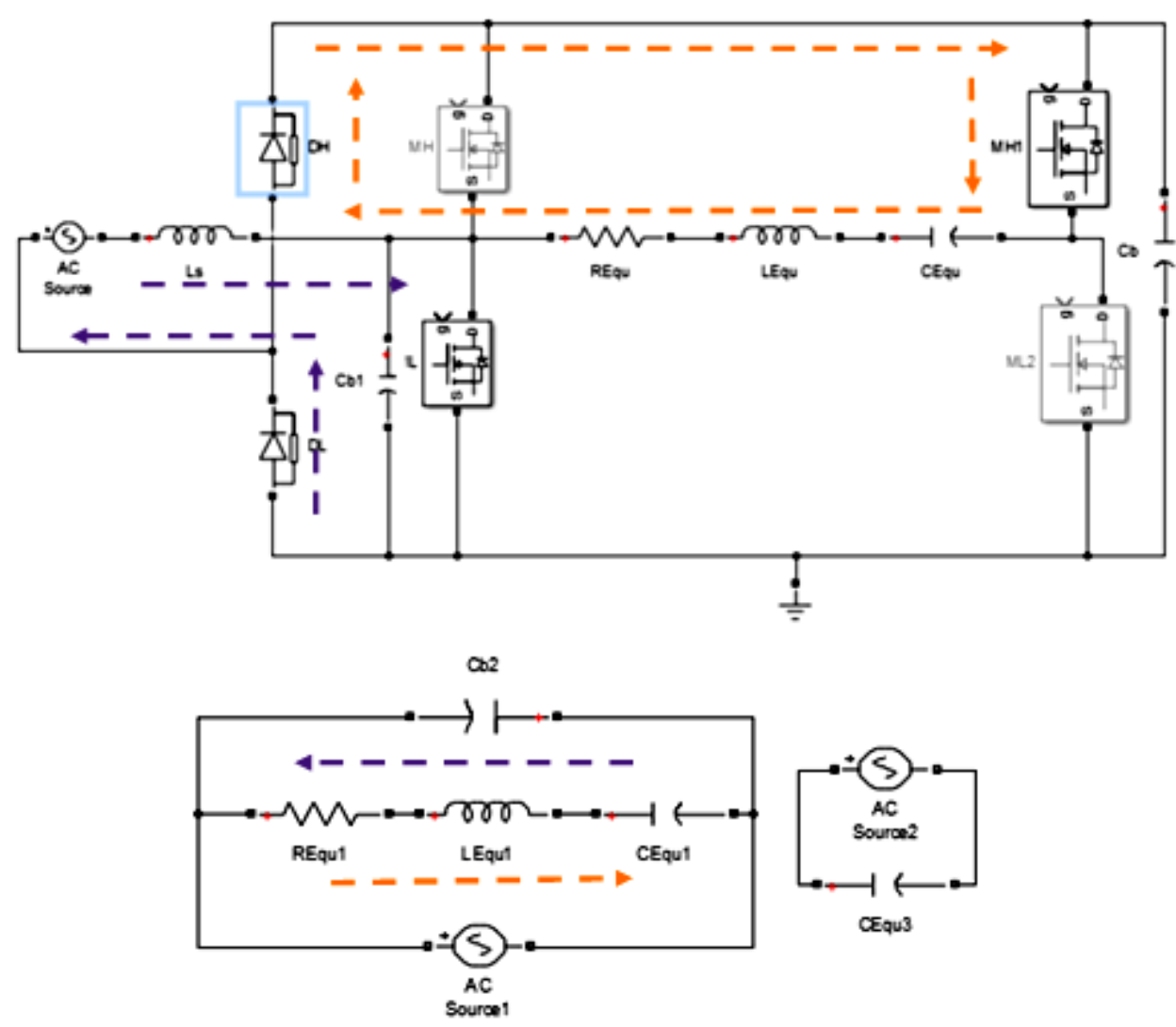

Figure 4. Mode 3: $\left(\mathrm{t}_{2}<\mathrm{T}<\mathrm{t}_{3}\right)$

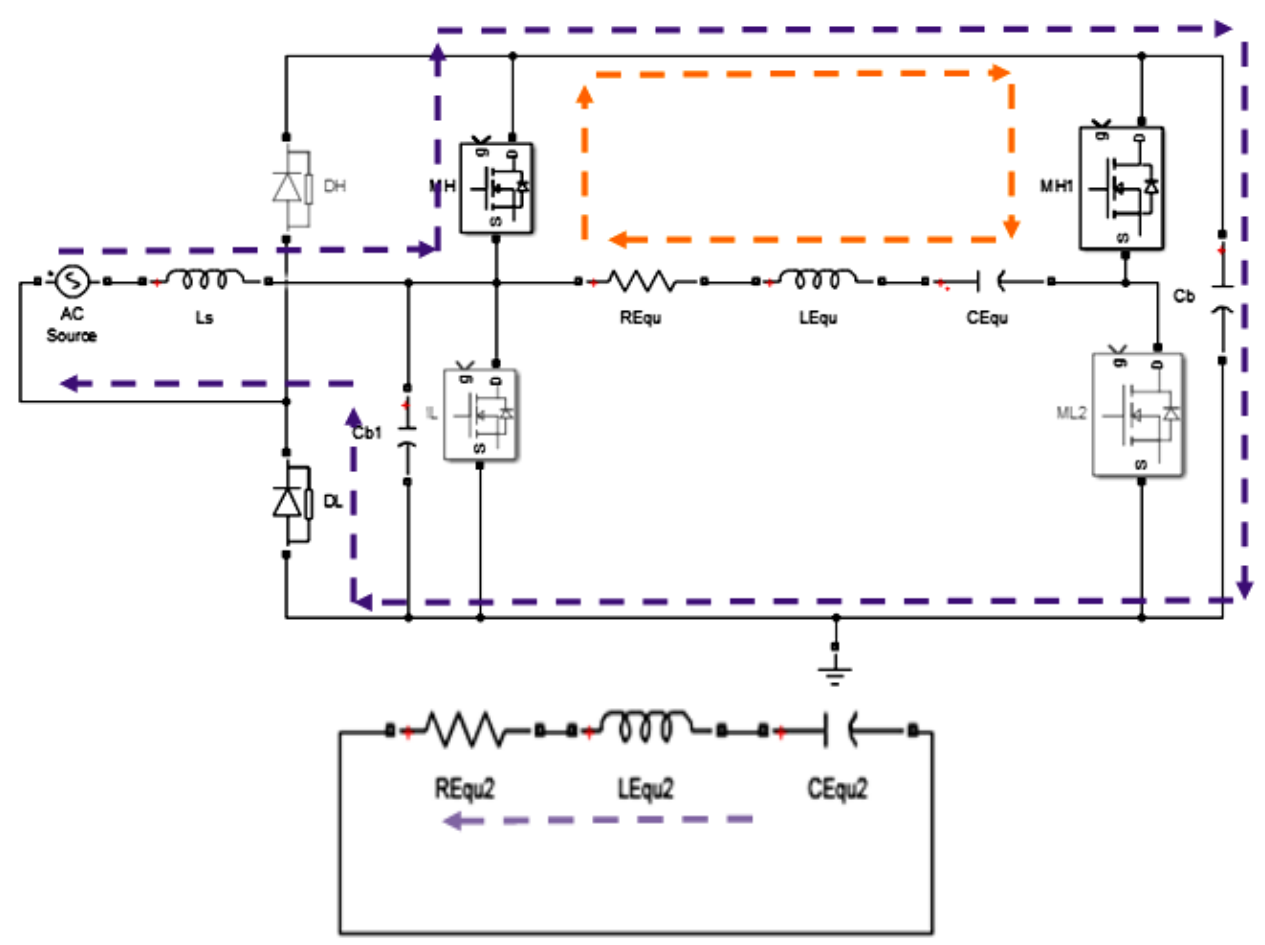

Figure 5. Mode 4: $\left(\mathrm{t}_{3}<\mathrm{T}<\mathrm{t}_{4}\right)$ 


\section{SIMULATION RESULTS}

Simulation of the proposed system was carried out for the asymmetrical pulse density signal the output waveforms of the simulated system is as in the Figure 6. The waveform of the filtering elements in the input part is also shown in Figure 7. The on time of the switch is restricted to $30 \%$ and the respective power output is also shown in Figure 8 the output power reached with this technique is $1.8 \mathrm{Kwatts.}$
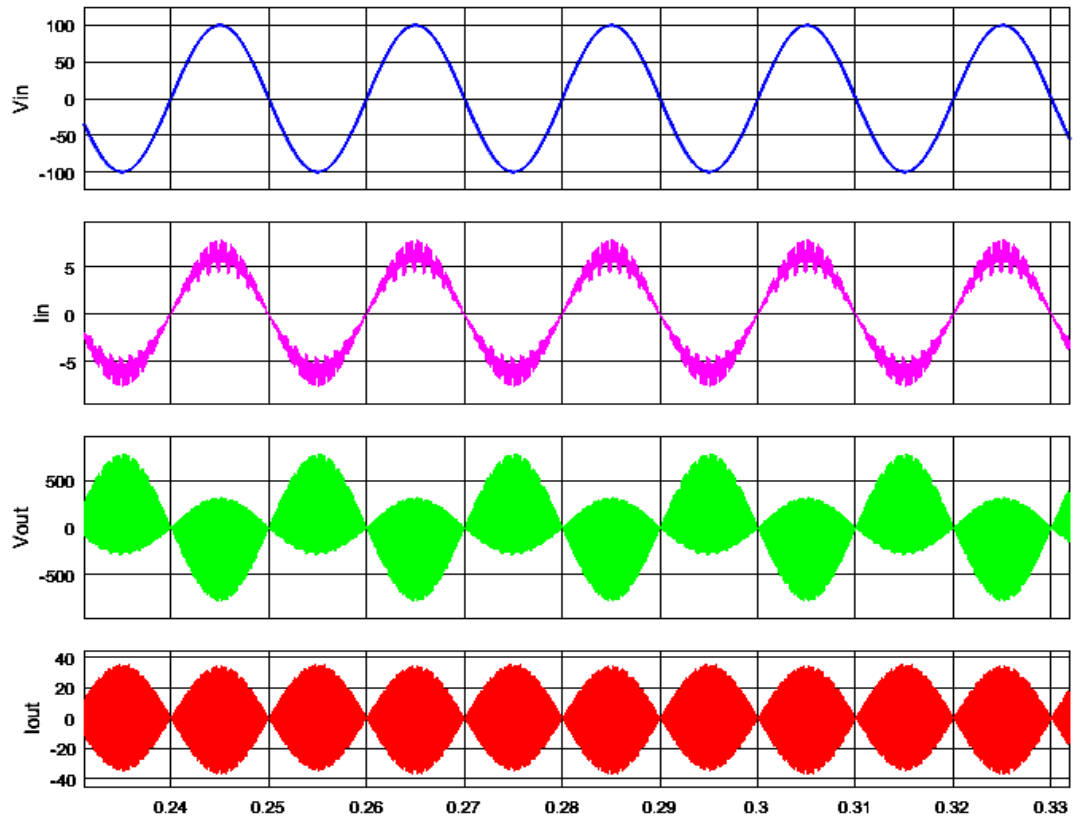

Figure 6. Asymmetrical pulse density modulated output waveform
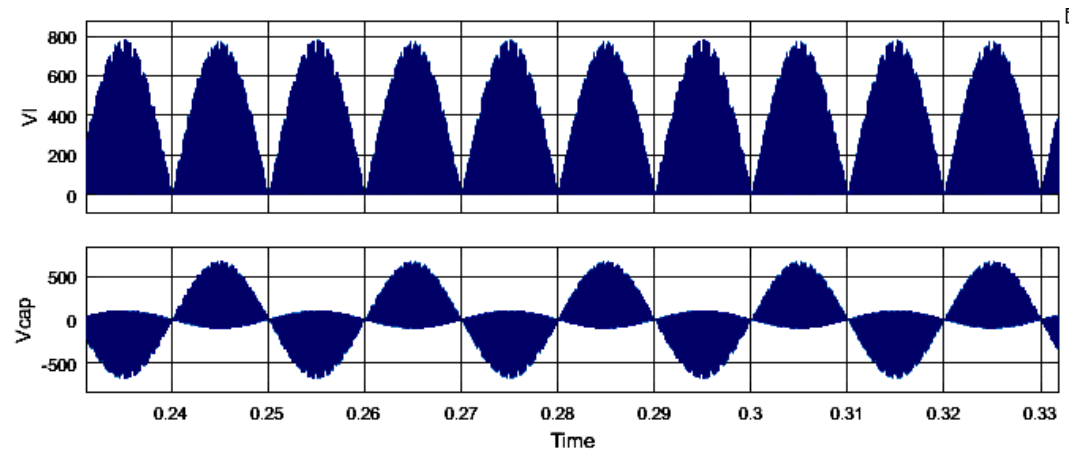

Figure 7. Voltage across filtering component

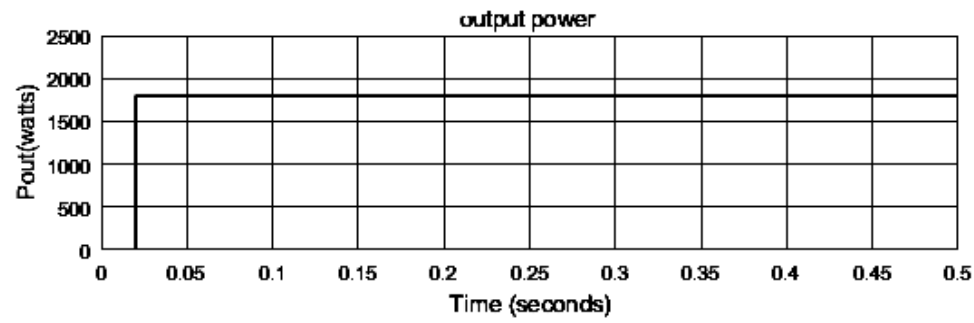

Figure 8. Pout VS time(ms) curve 
The total harmonic content of the output current is analysed by FFT analysis tool and found to be lesser compared to the symmetrical pulse density modulation. The filtering components in the input part of the circuit filters the maximum harmonic content in the output and provides us the undistorted output waveforms and the FFT analysis depicts the THD level of the output current produced in the coil.practically in the simulation it is found the the harmonics level is $13.43 \%$ which is less compared to the symmetrical pulse density modulated output in Figure 9. Simulation results for symmetrical pulse density modulated full bridge series resonant converter is as follows and the results produced at the output of the system and the filtering elements are depicted in Figure 10 and the output power verses the time curve is shown in Figure 11. The output power is found to be $2.89 \mathrm{Kw}$. Figure 12 depicts the waveforms of the filtering component and here THD is calculated practically and found to be $36.66 \%$ in Figure 13.
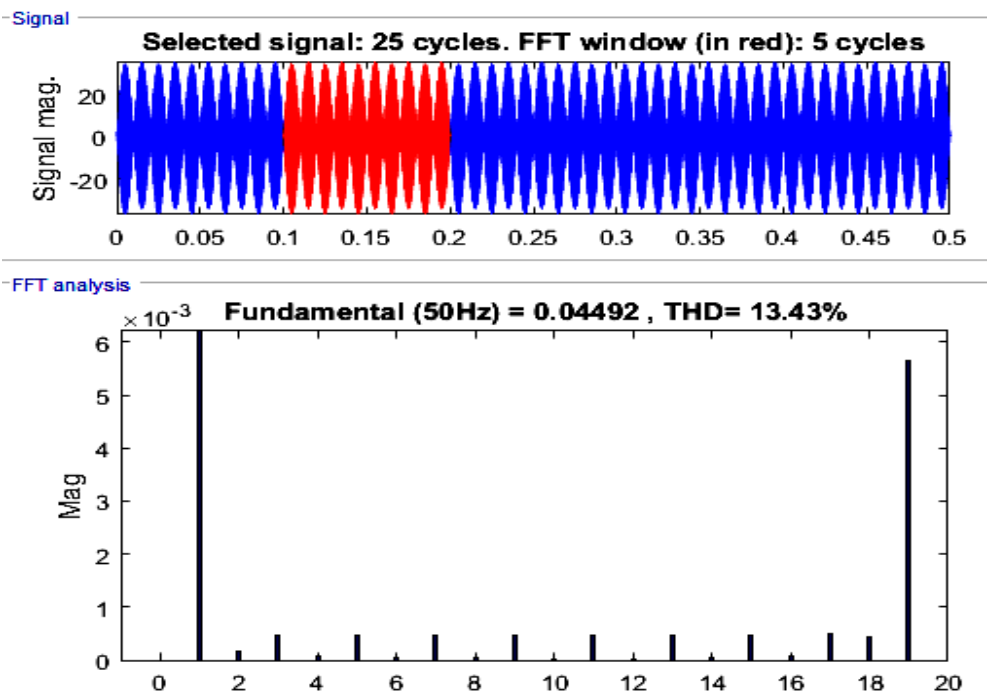

Figure 9. THD of output current produced in the proposed system
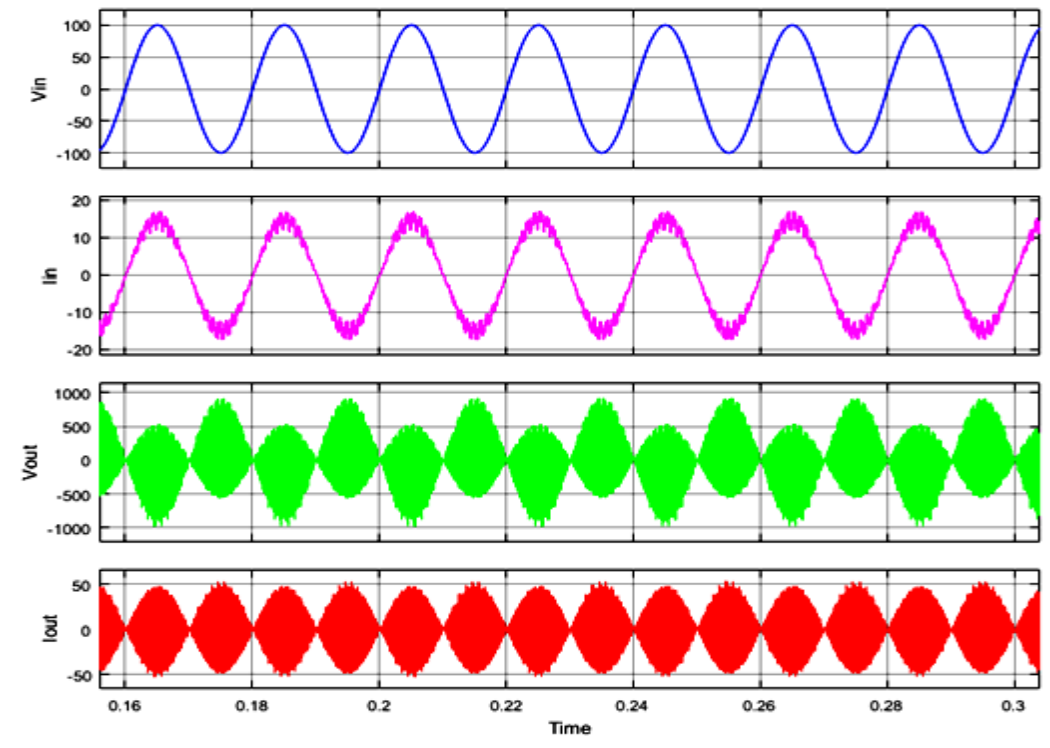

Figure 10. Symmetrical pulse density modulated output waveforms of full bridge series resonant converter 

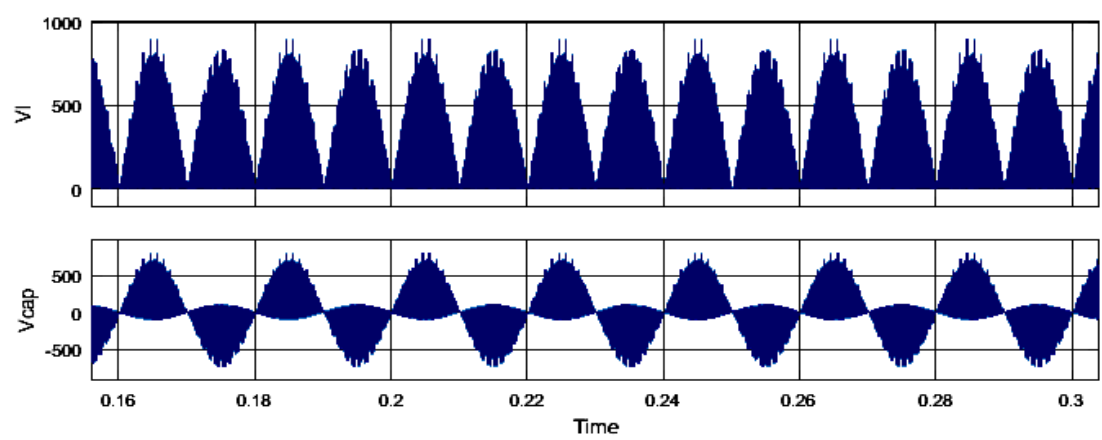

Figure 12. Voltage across the filtering element

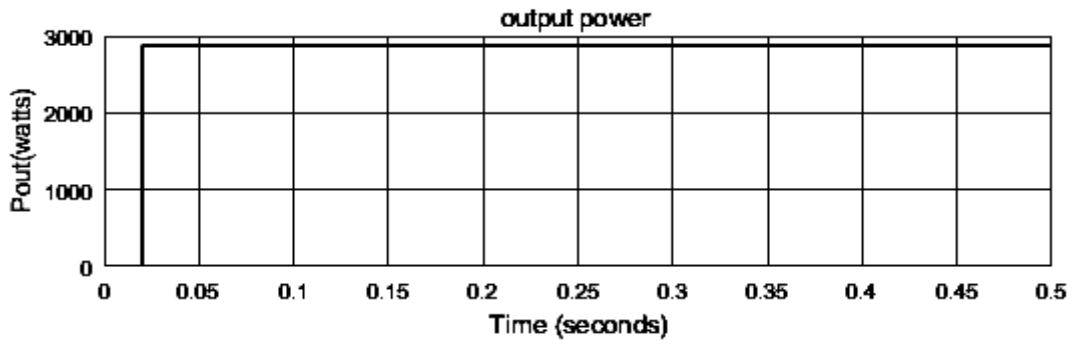

Figure 11. Output power VS T time(ms)

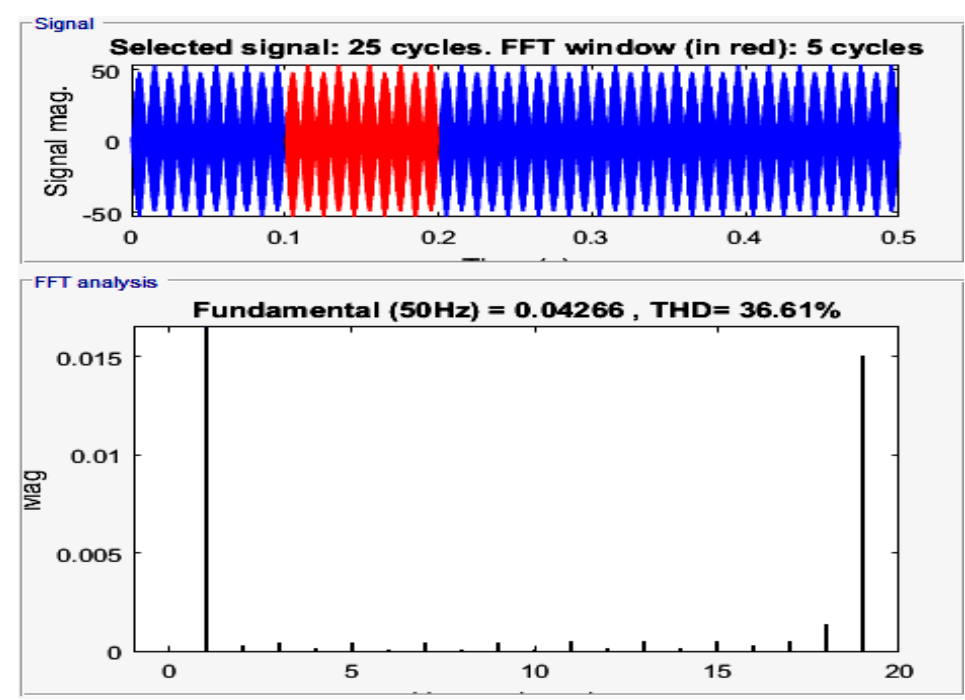

Figure 13. THD of the output current for the proposed system

Here the asymmetrical pulse density modulated and symmetrical pulse density modulated signals are compared and the comparison chart is shown in the Table 2. The result of the system is as tabulated in the following Table 2 .

Table 2. Result comparison

\begin{tabular}{lcc}
\hline Parameter & $\begin{array}{c}\text { Asymmetrical } \\
\text { modulated output }\end{array}$ & $\begin{array}{c}\text { Symmetrical } \\
\text { modulatedoutput }\end{array}$ \\
\hline Vout(volts) & 124.9 & 150.4 \\
Iout(amps) & 13.26 & 21.02 \\
Pout(kw) & 1.8 & 2.8 \\
THD\% & 13.43 & 36.61 \\
Power factor & 1.08 & 0.9 \\
\hline
\end{tabular}




\section{CONCLUSION}

The system simulated for the design of the induction heating system for domestic application. The above depicted results on comparison explicit the performance of the system. Here the asymmetrical pulse density modulated and symmetrical pulse density modulated signals are compared and the comparison chart is shown in the Table 2 . The results have a contradictory view like we could see the THD of the simulated system to be $13.43 \%$ and $36.63 \%$ for the respective system and on behalf of power is found to be $1.8 \mathrm{KW}$ and $2.8 \mathrm{KW}$ in the respective part of the system. Power factor of the system simulated is calculated by comparing the phase difference between the output voltage and output current.

\section{REFERENCES}

[1] Oscar Lucía,Pascal Maussion, Enrique J. Dede,José M. Burdío, "Induction heating technology and its applications, past developments, current technology,and future challenges," IEEE Transactions On Industrial Electronics, vol. 61 , no. 5, May 2014

[2] Kunapuli sahiti and V.Geetha, "Simulation of series resonant inverter using pulse density modulation," ARPN journal of engineering and applied sciences, vol.10, no.7, pp.3045-3051, Apr 2015.

[3] V.Geetha, V.Sivachidambaranathan," An overview of designing an induction heating system for domestic applications," International Journal of Power Electronics and Drive System (IJPEDS), ISSN: 2088-8694, Vol. 10, No. 1, pp. 351 356, March 2019.

[4] V.Geetha, V.Sivachidambaranathan, "A Single switch parallel quasi resonant converter topology for induction heating application," International Journal of Power Electronics and Drive System (IJPEDS), vol.9, no.4, pp. 1718-1724, Dec 2018.

[5] Pradip Kumar Sadhu, Palash Pal, Nitai Pa and Sourish Sanyal, "Selection of power semiconductor switches in m.h.b.r.i. fitted induction heater for less harmonic injection in power line," International Journal of Power Electronics and Drive System (IJPEDS), vol. 6, no. 1, pp. 121-128,Mar 2015.

[6] K. Selvamuthukumar, M. Satheeswaran, A. Ramesh Babu, "Single phase thirteen level inverter with reduced number of switches using different modulation techniques," ARPN Journal of Engineering and Applied Sciences, vol. 10, no. 22, pp.10455-10462,2015.

[7] ShoheiKomeda,Hideaki Fujita,"A phase-shift-controlled direct AC-to-AC converter for induction heaters," IEEE Transactions on Power Electronics, vol. 33, no. 5, pp.4115-4124, 2018.

[8] T.Mishima, S.Morinaga and M.Nakaoka, "All-SiC power module-applied single-stage ZVS-PWM AC-AC converter for high-frequency induction heating,"Proc. 41st Annual. Conf. IEEE Ind. Electron. Soc, pp. 4211-4216, 2015.

[9] H. Sarnago, O. Lucia, A. Mediano, and J.M. Burdıo, "DirectAC-ACresonant boost converter for efficient domestic induction heating applications," IEEE Trans. Power Electron., 2014.

[10] TomokazuMishima, Shuichi Sakamoto and Chiaki Ide, "ZVS phase-shift PWM-controlled single-stage boost fullbridge AC-AC converter for high-frequency induction heating applications," IEEE Transactions On Industrial Electronics, vol. 64, no. 3, 2017.

[11] T. Mishima, Y. Nakagawa, and M. Nakaoka, "A bridgeless BHB ZVS PWM AC-AC converter for high-frequency induction heating applications," IEEE Trans. Ind. Appl., vol. 51, no. 4, pp. 3304-3315, 2015.

[12] M.Pérez-Tarragona,H.Sarnago, Ó.Lucía, J. M. Burdío, "Full bridge series resonant multi-inverter featuring new 900-V SiC devices for improved induction heating appliances," IEEE Applied Power Electronics Conference and Exposition, pp. 1762-1766, 2016.

\section{BIOGRAPHIES OF AUTHORS}

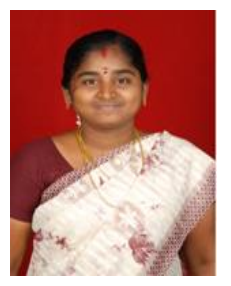

V.Geetha has received her B.E degree in Electrical and Electronics Engineering from Anna university, Tamilnadu, India in 2005 and M.E degree in Power electronics and industrial drives from Sathyabama institute of science and technology, Tamilnadu, India in 2008. She is pursuing her Ph. D under the faculty of Electrical and Electronics Engineering at Sathyabama Institute of Science and Technology from 2015. Her research interest includes Fuzzy logic controller, Artificial Neural network and Power Electronic Converters for induction heating application.

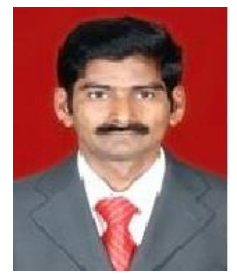

V. Sivachidambaranathan received his M.E. degree in Power Electronics and Industrial Drives from Sathyabama Institute of Science and Technology, Chennai in 2005 and obtained his Ph.D. degree in the Faculty of Electrical Engineering from Sathyabama institute of science and technology Chennai in the year 2013. He is currently working as Associate Prof. and Head of the Department of Electrical and Electronics Engineering, Head - Internal Exam Cell, at Sathyabama Institute of Science and Technology, Chennai. His research interest includes power converter, drives and control and renewable energy sources. 